Citation:

O'Kelly B.C. and Pichan S.P. (2013) Effects of decomposition on the compressibility of fibrous peat - A review. Geomechanics and Geoengineering:

An International Journal, 9(4): 286-296

DOI: $10.1080 / 17486025.2013 .804210$,

http://www.tara.tcd.ie/jspui/handle/2262/67443

\title{
Effects of decomposition on the compressibility of fibrous peat - A review
}

\section{Brendan C. O’Kelly}

Department of Civil, Structural and Environmental Engineering, Trinity College Dublin, Dublin 2, Ireland.

E-mail bokelly@tcd.ie Tel. +35318962387

\section{Som P. Pichan}

Public Works Department of Malaysia,

Kuala Lumpur, Malaysia.

Formerly Postgraduate Researcher, Department of Civil, Structural and Environmental Engineering, Trinity College Dublin, Ireland.

E-mail Sompong@jkr.gov.my

Corresponding author: Brendan O’Kelly

First submission: 29th June 2012

Resubmission: 22nd March 2013.

Number of Tables: None

Number of Figures: 11

Word count (excluding bibliography): 6200 


\begin{abstract}
Peat deposits are comprised of high organic content substances primarily derived from dead plant vegetation. Peat itself is not inert but undergoes continuous biological decomposition that causes progressive destruction of the peat fabric, reductions in fibre and organic contents and biogas generation. Depending on the degree of decomposition, the organic solids can exist as fresh (intact) fibres, slightly decomposed or ultimately completely decomposed (amorphous) material. From a geotechnical perspective, an understanding of the relationship between degree of decomposition and engineering properties, including the level of compressibility, is important in dealing with such problematic deposits. However a review of the literature indicates that such relationships have not been sufficiently investigated. Moreover, potential impacts of uncontrolled or unexpected decomposition in-situ are regularly discounted in geotechnical practice. This paper reviews decomposition effects in peat and potentially significant knock-on effects in terms of the material's physical properties and compressibility. Progressive reduction in solids volume and deterioration in the integrity of the organic structure due to on-going decomposition may cause significant additional settlement to occur over time. More decomposed peat generally undergoes lower primary consolidation and creep strains and is also less prone to future decomposition, compared with lesser decomposed peat.
\end{abstract}

Keywords: compression, creep, fibre, peat, organic, soil.

\title{
1. INTRODUCTION
}

Peat (mire) deposits are composed of naturally-occurring high organic content substances, primarily derived from plant vegetation. The organic content can exceed $98 \%$ by dry mass, of which up to $95 \%$ is attributed to partially decomposed vegetation and residual organic compounds arising from the decomposition process (Wong et al., 2009). Depending on botanical composition and degree of decomposition, the main constituents are: i) coarse fibres derived from plant stems and roots greater than $1 \mathrm{~mm}$ in diameter; ii) fine fibres from plant leaves, stems and roots smaller than $1 \mathrm{~mm}$ in diameter; iii) amorphous (structure-less) matter having a granular appearance (Hobbs, 1986). These solids accumulate in-situ on account of the slow decomposition rate of dead plant vegetation under prevailed waterlogged conditions, with decomposition failing to keep up with the plant growth rate at the mire surface (Farrell, 2012). Hence partially decomposed vegetation accumulates over time, with this process repeated over timescales of $10^{2}$ to $10^{3}$ years (Mesri and Ajlouni, 2007; Wong et al., 2008). The peat deposits formed are composed of partially decomposed remains of vegetation having different states of decomposition over the depth profile. Material consisting mainly of fresh (intact) fibres to slightly decomposed plant material is referred to as fibrous peat. Somewhat decomposed and mostly decomposed materials normally found in deeper layers are known as hemic and sapric peats respectively. The terms acrotelm and catotelm have also been used to distinguish between different layers of peat deposits in natural ecosystems, based on seasonal groundwater level or degree of decomposition. On the von Post peat classification system (Landva and Pheeney, 1980), the degree of decomposition is classified by determining a humification $(\mathrm{H})$ number, 
ranging between one and 10; where $\mathrm{H} 1$ signifies peat that has undergone no decomposition and $\mathrm{H} 10$ is completely decomposed material. Although the term humification strictly means the content of humic substances, in this context, it is taken to mean the same thing as decomposition. Peat can be further classified based on its fibre content. Fibric peat (H1 to H4) is comprised of more than $66 \%$ fibres by dry mass whereas hemic (H5 to $\mathrm{H} 7$ ) and sapric (H8 to $\mathrm{H} 10$ ) peats are comprised of 33-66\% and less than 33\% fibres respectively (ASTM D4427, 2007). Because of the subjective nature of these classifications, results can vary widely and should only be treated as an indication of peat type. Quantitative measurement of the fibre content of peat (Lévesque and Mathur, 1979; ASTM D1997, 2008) and extracted humic substances (Schnitzer 1967; Rochus and Sipos, 1976) have been noted as more reliable indicators of peat decomposition. Representative test-specimens of the peat are washed on the $150-\mu \mathrm{m}$ sieve in order to separate out the peat fibres and the fibre content determined by expressing the oven-dried mass of the retained material as a percentage of the specimen dry mass.

Decomposition of the partially decomposed plant matter is an on-going process, driven by consortia of microorganisms (including bacteria and fungi) that use the decaying organic matter as an energy source and building material (Hobbs, 1986; Huat et al., 2011; Kazemien et al., 2011; Pankratov et al., 2011). Pichan and O'Kelly (2013) reported mean microorganism counts of the order of $10^{5}$ colony-forming units (CFU)/g for moderately decomposed Sphagnum peat (dry mass basis); consistent with the value of $\sim 2.6 \times 10^{5} \mathrm{CFU} / \mathrm{g}$ reported by Hunter et al. (2006). However large variations in microorganism populations in mire naturally occur with depth (Barns and Nierzwicki-Bauer, 1997). According to Pichan and O'Kelly (2013), the microorganisms in the Sphagnum peat considered were mostly facultative in character (i.e. can live with or without oxygen), with greater populations forming under aerobic incubation, which is more favourable for bacterial growth.

The decomposition process can be accelerated as a result of more favourable environmental conditions, created naturally or by anthropogenic activity; e.g. constructed drainage schemes. In natural ecosystems, the decomposition rate may accelerate markedly as a result of intermittent fluctuations of the groundwater table, which causes air ingress and hence an increase in oxygen concentration within the deposit. Recent developments in microbiology have indicated that biological activity can be promoted by altering the limiting factors; e.g. by injecting oxygen and nutrients such as glucose or by changing environmental conditions (Mitchell and Santamarina, 2005). Studies by Pichan and O' Kelly $(2012,2013)$ have also indicated that the decomposition rate for fibrous peat can be accelerated by altering Carbon: Nitrogen ratio $(\mathrm{C}: \mathrm{N})$, $\mathrm{pH}$, oxygen supply and temperature for optimum decomposition conditions. Since peat mostly comprises carbon, with only traces of nitrogen, its C:N ratio is naturally high; generally in the range of 40:1 to 50:1. For instance, from elemental analysis of moderately decomposed Sphagnum peat from a raised bog, Pichan and O'Kelly (2013) reported total carbon and nitrogen contents of 54.2 $\pm 1.3 \%$ and $1.25 \pm 0.03 \%$, respectively, indicating a mean $\mathrm{C}: \mathrm{N}$ ratio of approximately $43: 1$. An increase in the proportion of nitrogen results in higher microbial activity (Hobbs, 1986; Pankratov et al., 2011), with the optimum $C: N$ ratio for decomposition in the range of 15:1 to 30:1 (Wardwell et al., 1983). Microbial activity in mire is also retarded by high acidity and relatively low temperature. For a balanced reaction, the decomposition process requires a near-neutral $\mathrm{pH}$ (Wardwell et al., 1983), with decomposers most active over the $\mathrm{pH}$ range of 7.0-7.5. The optimum temperature for decomposition of organic matter present as cellulose occurs in the 
range of $35-40^{\circ} \mathrm{C}$ (Hobbs, 1986; O'Kelly, 2006). Hobbs (1986) reported that the decomposition process can reach completion in mire exposed to a consistent temperature of $20-30^{\circ} \mathrm{C}$ and for $\mathrm{pH}$ $>5$.

Pichan and O'Kelly (2013) presented a feasibility trial of a technique designed to accelerate the decomposition process in peat; achieved by adding sufficient amounts of basic and nitrogenous materials to the peat in order to adjust its $\mathrm{C}: \mathrm{N}$ ratio and $\mathrm{pH}$ within optimum ranges for decomposition to occur. In a demonstration for a moderately decomposed fibrous Sphagnum peat, peat pulverised fuel ash (PPFA) and urea were selected as the additives, with $30 \%$ PPFA and $2.2 \%$ urea (based on the peat dry mass), equivalent to $\sim 21 \mathrm{~kg}$ PPFA and $\sim 1.5 \mathrm{~kg}$ urea per cubic meter of wet peat, producing values of $\mathrm{C}: \mathrm{N}$ ratio and $\mathrm{pH}$ within reported optimum ranges. In follow on work, specimens of the natural peat and peat-PPFA-urea mixture have been decomposed either aerobically or anaerobically at a constant temperature of $30^{\circ} \mathrm{C}$. Measured populations of microorganisms were significantly greater for the peat-PPFA-urea mixture

(Figure 1), with $\sim 1.2 \times 10^{9} \mathrm{CFU} / \mathrm{g}$ recorded under aerobic incubation after 42 days; in excess of 1800 and 3500 times average initial values for the natural peat and peat mixture respectively. Microorganism populations in the peat mixture also appeared to remain approximately steady over the 126-day incubation period considered. However further research is necessary to establish and quantify changes in physical and mechanical properties brought about by these significant increases in microorganism populations within the peat.

Figure 1: Population of microorganisms in natural peat and peat-PPFA-urea mixture at $30^{\circ} \mathrm{C}$ against duration of incubation period.

Since the physical and mechanical properties of peat are dominated mainly by organic content and structural fabric, peat material can be expected to behave differently over an extended period of time due to gradual changes in its organic constituents. Destruction of the physical structure of the fibres, reduction in organic content through transformation of organic matter into humic substances and conversion into gases at the final stage of decomposition have a significant influence on the compressibility of peat. However the direct effects of decomposition on the compression behaviour and properties of peat have not been investigated sufficiently due to the pervading consensus in geotechnical literature and practise that the decomposition rate in peat is extremely slow under anoxic conditions and hence does not cause significant effects over the design life of pertinent engineering works (Hobbs, 1986). However some researchers have suggested that certain long-term deformations observed in peats may be more related to the effects of biological activity than the response to mechanical stress (Wardwell et al., 1983). The aim of this paper is to present a critical review of potential effects of the decomposition process on the compressibility of fibrous peat.

\section{PHYSICAL PROPERTIES}

Before looking at the compressibility characteristics of peat, it is important to consider the nature of the peat fabric; i.e. geometrical aspects of a particle, associated inter-particle forces and spatial 
arrangement, shape and size of the fibres. The overall peat fabric is an assemblage of decaying plant cellular structures, entangled by frequent fibres and leaves, which are in a less decayed state. For example, fibrous peat originating mainly from Sphagnum mosses generally consists of fibres ranging from 0.074 to $2.0 \mathrm{~mm}$ in size, comprising on average of $10-15 \%$ stem, $85-90 \%$ leaves and leaf fragments, with less than $10 \%$ of the solids smaller than $0.074 \mathrm{~mm}$ (Landva and Pheeney, 1980). The structural arrangement of the fibres is highly dependent on the parent plant, the circumstances in which the peat was formed and its degree of decomposition. For example, given the genesis of raised bogs and vegetation growth patterns, their geotechnical and hydraulic properties are not uniform in either the vertical or horizontal direction, even over short distances.

The highly porous, cellular structure of the constituent fibres (Figure 2) is mostly full of water, with one- to two-thirds of the water content of fibrous peat contained within the particles themselves (Landva and Pheeney, 1980; O'Kelly and Zhang, 2013). Hence fibrous peat has high water content, generally between $500 \%$ and $2000 \%$ by dry mass (Mesri and Ajlouni, 2007; Farrell, 2012). Water is held as intracellular water within internal cells (micropores), interparticle water by capillary forces (macropores) and adsorbed water; with their relative proportions and total quantity mainly depending on the structure, morphology and degree of decomposition of the various plants (Hobbs, 1986; Farrell, 2012; O'Kelly, 2013). Water content can also be influenced by the high cation exchange ability of the peat forming plants (particularly in the case of Sphagnum mosses), which governs the thickness and rigidity of the adsorbed water layer (Hobbs, 1986). This produces stronger adsorption complex and greater inter-particle adherence, which contributes to higher values of water content and also of liquid limit for fibrous peat (Hobbs, 1986; Huang et al., 2009; Huat et al., 2011). With increasing decomposition, the strength of the adsorption complex steadily weakens as plant tissues are broken down.

Figure 2. Scanning electron micrograph of pseudo-fibrous Sphagnum peat.

Fibrous peat also has very low specific gravity of solids values, mainly attributable to cellulose and lignin which are the principal constituents of the organic matter. Low specific gravity of solids values are reflected in very low values of bulk density, typically between 9.5 and 11.5 $\mathrm{kN} / \mathrm{m}^{3}$. Fibrous peat with an organic content of greater than $90 \%$ typically has specific gravity of solids values in the range of 1.4 to 1.6 (Mesri and Ajlouni, 2007; Huang et al., 2009); consistent with reported values of 1.4 to 1.5 for cellulose and lignin (Hobbs, 1986). Specific gravity can be affected by the proportion of inorganic material, which can be related to the mineral content and degree of decomposition (O'Kelly, 2006). Higher values of specific gravity generally indicate higher mineral content and (or) higher states of decomposition (Hobbs, 1986; Huat et al., 2011). Bulk density and void ratio may also be influenced by the presence of internal gases generated by the decomposition process, occurring either as free gas in the macropores or entrapped gas in micropores. These gases generate a buoyancy effect for submerged peat material (Huang et al., 2009). Fibrous peat typically has a very high shrinkage capacity, reducing in volume by up to $50 \%$ on air drying (Huat et al., 2011). The shrinkage potential in the vertical and horizontal directions is different since the plant structures tend to shrink more across the fibres than along their length (Hobbs, 1986), with the fibres often orientated in a general horizontal alignment insitu (Yamaguchi et al, 1985; Zhang and O'Kelly, 2013). Shrinkage of the thin-walled tissues and 
collapse of the cellular structure produces a reduction in the water holding capacity and particle porosity (Wong et al., 2009).

\section{COMPRESSIBILITY CHARACTERISTICS}

The compressibility and consolidation behaviour of peat is quite distinct from other soils since its response is greatly influenced by the size, shape, fabric and arrangement of the constituent fibres (Mesri and Ajlouni, 2007; Wong et al., 2009; O'Kelly, 2009) and requires special considerations in laboratory testing procedures and interpretation of results. Peat is extremely compressible under loading, experiencing high initial rates of primary consolidation and substantial creep (Landva and La Rochelle, 1983; Santagata et al., 2008; Wong et al., 2009), with the creep component often greater than the primary consolidation (hydrodynamic) component (Farrell, 2012). In addition to the secondary compression component (i.e. strain increasing in direct proportion to logarithm of elapsed time), a tertiary compression stage usually occurs for fibrous peat, in which case the creep strain rate can increase substantially (Dhowian and Edil, 1980); the higher the fibre content, the greater the tertiary strain (Colleselli et al., 2000; Wong et al., 2009). The compression behaviour of peat generally deviates significantly from Terzaghi's consolidation theory, which strictly means that geotechnical methods intended for analysing the compression response of mineral soils are inapplicabile for peat ( $\mathrm{Ng}$ and Eischens, 1983; Hobbs, 1986; Wong et al., 2009; Farrell, 2012). Peat generally has high values of primary compression index $\left(C_{c}\right)$, secondary compression index $\left(C_{\alpha}\right)$ and of the $C_{\alpha} / C_{c}$ ratio (Mesri and Ajlouni, 1997; Colleselli et al., 2000). The compressibility of fibrous peat is also strongly cross-anisotropic (Zwanenburg, 2005; Wong et al., 2009), arising from the general horizontal alignment of the constituent fibres in-situ (Yamaguchi et al, 1985; Zhang and O'Kelly, 2013). For example, O'Kelly (2006) reported one-dimensional compression data for sets of undisturbed specimens prepared in the vertical and horizontal directions from adjacent sections of carefully sampled borehole cores. Over the applied stress range of 12 to $50 \mathrm{kPa}$, the horizontal to vertical ratio of the primary compression index and secondary compression index were 0.9 and 0.6 , respectively, for spongy fibrous $\mathrm{H} 3$ peat (Figure 3) indicating that the compression and in particular creep behaviour were strongly cross anisotropic.

Figure 3. Compression properties of fibrous peat for vertical and horizontal loading directions.

The extreme compressibility of fibrous peat is strongly linked to its very high void ratio, typically ranging between 7.5 and 30 , which has been mainly attributed to its comparatively large and highly porous particles (Mesri and Ajlouni, 2007; Huat et al., 2011; Farrell, 2012). This influences the permeability and sequential expulsion of water from macro- and micro-pores, which govern the rates of primary consolidation and creep settlements (Berry, 1983; Huat et al., 2011). The high rate of primary consolidation for fibrous peat occurs due to its high initial permeability, with typical hydraulic conductivity values in the range of $10^{-5}$ to $10^{-8} \mathrm{~m} / \mathrm{s}$; approximately 10 to $10^{3}$ times greater than that for soft clay/silt deposits (Mesri and Ajlouni, 2007; Huang et al., 2009; Huat et al., 2011). The anisotropic compressibility displayed by fibrous 
peat is associated with its high degree of permeability anisotropy (ratio of hydraulic conductivity values for flow in the horizontal to vertical directions, $r_{\mathrm{k}}$, as high as 10), which is attributed to the predominantly horizontally-orientated and laminated nature of the fibres (Yamaguchi et al. 1985; Mesri and Ajlouni, 2007; Huang et al., 2009; Huat et al., 2011). Exceptions also arise, for example, under low applied stress and at shallow depths where preferential flow conduits provided by vertically-aligned root holes may give rise to $r_{\mathrm{k}}$ values less than unity; i.e. macro hydraulic conductivity greater for vertical flow conditions (O'Kelly, 2007). However closure of the root holes and the tendency for constituent fibres to realign in a more general horizontal direction during subsequent loading causes more significant reductions in permeability for the vertical than horizontal direction, producing values of $r_{\mathrm{k}}>1$.

Hydraulic conductivity decreases dramatically under compression due to large reductions in void ratio and changes in the size, shape and direction of the flow channels (Mesri and Ajlouni, 2007; O'Kelly, 2007). Huang et al. (2009) reported that reductions in the rate of water expulsion from micropores to macropores, combined with the high degree of permeability anisotropy, resulted in significant long-term settlement occurring in fibrous peat deposits under compressive loading. The magnitude of the settlement is also influenced by the high compressibility of the organic solids and porosity of the peat fibres themselves (Berry, 1983; Landva and La Rochelle, 1983; Zhang and O'Kelly, 2013). Upon load application, fibrous peat typically undergoes an elastic compression due to the presence of internal gases (Kazemien et al., 2011). However any sustained loading produces non-reversible compression (creep) of the intricate system of cells and baffle walls that reinforced the peat fabric (Landva and La Rochelle, 1983, Farrell, 2012). The rate of creep generally increases with increasing organic content due to the higher porosity (Landva and La Rochelle, 1983).

\section{EFFECT OF DECOMPOSITION PROCESS ON ORGANIC MATTER}

It has been recognised that the decomposition process involves: i) loss of organic matter, either in gas or in solution; ii) disappearance of physical structure; iii) change in chemical state of organic matter (Hobbs, 1986; Huat et al., 2009; Kazemian et al., 2011). Plant vegetation is broken down by microorganisms which use the decaying organic matter as both an energy source and building material. The process is one of biochemical oxidation since the end products of decomposition are generally carbon dioxide and water (Hobbs, 1986). In non-acidic conditions, earthworms can enhance the breakdown of the cellular structure of plant remains. In later stages, bacteria and fungi cause the transformation into humic substances (Hobbs, 1986; Tate, 1987), major classifications of which are humic acids, fulvic acids and humin. These are complex series of relatively high molecular weight yellow-black organic substances formed by secondary synthesis reactions (Santagata et al., 2008) and which are more recalcitrant to further decomposition.

Landva and Pheeney (1980) performed a comprehensive study that involved the examination of Sphagnum and sedge peat samples at different stages of decomposition in order to determine the effects of decomposition on plant tissues in peat. The inner cell walls of Sphagnum mosses do not contain lignin and are primarily composed of degradable compounds in the form of cellulose 
and some non-cellulosic polysaccharides, including pectic polysaccharides (Pankratov et al., 2011).

Hence, during the decomposition process, soft inner cell walls within the leaf, stem and root components of constituent plants are attacked first (Hobbs, 1986; Farrell, 2012). The rate of decomposition for the harder outer teguments is generally substantially slower due to the presence of various highly decay-resistant compounds such as phenolic and waxes (Pankratov et al., 2011). The breakdown of cellulose within the plant tissues produces reductions in size and strength of the fibres (Hobbs, 1986; Wong et al., 2009) and ultimately some peat solids are lost by permanent material changes (Wardwell et al., 1983; Mesri and Ajlouni, 2007).

A complete decomposition process produces amorphous peat material, comprised of smaller and approximately equi-dimensional organic grains (Hobbs, 1986; Mesri and Ajlouni, 2007). In this case, the soil matrix mainly consists of gelatinous organic acids (humic substances) in the form of sponge-like solids (Landva and Pheeney, 1980; Hobbs, 1986; Farrell, 2012). Hence more decomposed peat has comparatively lower organic content and comprises a greater proportion of fine fibres than the least decomposed peat (Hobbs, 1986; Price et al., 2005; Huat et al., 2011; Kazemian et al., 2011). ASTM D4427 (2007) classifies amorphous peat as having a fibre content of less than $20 \%$, with most of the solid particles colloidal in size (i.e. $<2 \mu \mathrm{m}$ ).

The final stage of the decomposition process for organic soils involves the conversion of organic substances into humus, gases and water, which produces a reduction in total organic content. Gases can exist as free gas in the macropores or entrapped gas in micropores (Huang et al., 2009). The gas content is difficult to measure directly, with no widely recognized method currently available (Huang et al., 2009; Huat et al., 2011). However a gas content of between 5\% and $10 \%$ of the total volume has been reported for peat (Landva and La Rochelle, 1983; Hobbs, 1986; Huat et al., 2011). Gas bubbles form since the gas concentration exceeds its equilibrium solubility in the pore water (Kellner et al., 2005). Under waterlogged conditions, the gas bubbles remain trapped within the peat deposit, growing in size, until they are eventually released to the ground surface and atmosphere through an ebullition process (Couwenberg, 2009). The destruction of the plant remains and ensuing reductions in organic and fibre contents brought about by the decomposition process have a significant effect on the compressibility characteristics of peat (Wardwell et al., 1983; Farrell, 2012).

\section{EFFECT OF DECOMPOSITION PROCESS ON COMPRESSIBILITY OF PEAT}

Since organic content and structural fabric play important roles in the mechanical properties of peat, gradual changes occurring on account of on-going decomposition potentially have appreciable effects on compressibility. Pichan and O'Kelly $(2012,2013)$ have pointed out that from a geotechnical perspective, significant uncontrolled or unexpected decomposition occurring in peat may adversely impact on the performance of engineering structures founded on or within peat deposits. Total settlement may increase significantly on account of loss in solids mass (volume) associated with the microbial metabolism and deterioration of the structural integrity of the organic solids (Wardwell et al., 1983). Referring to Figure 4, lowering of the groundwater table causes a reduction in volume of the peat deposit on account of: i) stress increase on 
underlying peat layers and hence additional consolidation settlement as a result of the decrease in buoyancy; ii) shrinkage due to capillary forces along with high shrinkage capacity of the fibres on drying; iii) more rapid biological decomposition of the organic matter content under aerobic conditions (Drajad et al., 2003).

Figure 4: Settlement response caused by lowering of the groundwater table (Matthiesen, 2004).

Other disciplines, including agricultural, botanical and environmental, often attribute the decomposition process as the main cause of creep settlement occurring for land areas subject to natural periodic fluctuation of the groundwater table or following the construction of land drainage schemes, with the decomposition process stimulated by the more favourable environmental conditions. Experimental laboratory studies by Wardwell et al. (1983) indicated that total settlement is approximately $50 \%$ greater for organic deposits in which decomposition has been stimulated. Numerous case studies summarised by Pichan and O'Kelly (2013) indicate that the amount of creep settlement involved can be substantial, with significant implications for land use, planning and development of affected areas. For example, along with low shear strength and high compressibility of the bog foundation, stimulated decomposition may contribute significantly to increased distortion/undulation of the pavement surface (Figure 5), particularly in the case of rampart roads (Osario et al. 2008), necessitating high maintenance budgets in order to keep bog roads in service. For example, Cuddy (1988) reported that the cost of maintaining a bog road at similar performance levels to that of a road constructed on firm ground was about ten times greater.

Figure 5. Extreme undulations on N62 rampart road, Ireland (Osario et al. 2008).

To date, the compression response of peat deposits arising directly from on-going decomposition has not been properly quantified (Price et al., 2005). Furthermore, established methods are currently not available in literature for predicting potential settlements arising from the deterioration or biochemical removal of organic matter in peat (Matthiesen, 2004). A few methods for estimating decomposition settlement occurring during and post-filling of municipal landfills have been reported by Oweis (2006); e.g. $11 \%$ of the total $20 \%$ biodegradable content in municipal landfill was reported to have undergone decomposition during filling, with the other $9 \%$ decomposing over the following 40-year period. These methods require input values for parameters such as decay constant, with an average value of 0.05 reported by Oweis (2006) for the municipal landfill example. However values of the requisite parameters are currently unknown for peat, hindering the reliable application of such models in predicating settlement arising from the decomposition of peat deposits.

The decomposition rate in peat and other highly organic materials is generally determined indirectly by measurement of the gas volume released. The writers have developed different experimental set ups in order to decompose organic soils under controlled laboratory conditions and measure the rates of biogas production. In Figure 6(a), the test-specimen of approximately 
4.0 litres in volume is contained within a $250-\mathrm{mm}$ diameter hydraulic consolidation (Rowe cell) apparatus and allowed to degrade anaerobically, with accelerated biodegradation achieved by increasing the oven chamber temperature to typically $35^{\circ} \mathrm{C}$ (O'Kelly, 2005). Specimen drainage is allowed to occur and the volume of biogas evolved recorded against incubation time. If necessary, a confining pressure can also be applied to the test-specimen across the Rowe cell's bellofram diaphragm.

In the experimental set up shown in Figure 6(b), 250-mm long specimens A and B are contained in 110-mm diameter Perspex containers and incubated in a water bath, with specimen A fully submerged (i.e. anaerobic) and the top of specimen B maintained at some distance above the water level in the bath. Peat water from the bog is used to fill the bath in order to prevent any effects due to changes in water chemistry on the decomposition process. A cavity between the top of the specimen and container allows the specimen to potentially swell during incubation (i.e. no applied confining stress). Biogas is collected under water using an inverted graduated cylinder, via tubing connected to the top of the specimen container. In a demonstration of this technique, Pichan and O'Kelly (2012) incubated undisturbed specimens A and B of fibrous Sphagnum peat; with the top of specimen B located a distance of $200 \mathrm{~mm}$ above the water level in the bath, which was maintained at $30^{\circ} \mathrm{C}$. After a two-month incubation period, specimen $\mathrm{B}$ had undergone $2 \%$ axial expansion (with about half that measured for specimen $\mathrm{A}$ ) and the respective volumes of biogas collected from specimens A and B were 230 and $400 \mathrm{ml}$; corresponding to $0.16 \%$ and $0.28 \%$ of the wet specimen volume/day respectively. A change in colour of the peat core from dark brown to black was also observed near the top of specimen B. These decomposition rates are relatively low, presumably because other significant factors, including $\mathrm{C}: \mathrm{N}$ ratio and $\mathrm{pH}$ of the peat specimens, had not been adjusted for optimum decomposition conditions. However the approximately double the rate of biogas evolution and colour change produced for specimen B are consistent with its partially submerged condition.

Figure 6. Set-ups to measure volume of biogas evolving from peat and other highly organic soils. (a) Anaerobic biodegradation at elevated temperature (O'Kelly 2005).

(b) Incubation of submerged and partially submerged peat cores (adapted from Pichan and O’Kelly (2012)).

Although Wardwell et al. (1983) reported complete conversion of organic substrate into gases is not considered to be responsible for the increase in compressibility of organic deposits, the presence of gases has nevertheless been proven to affect the compressibility of peat since the dynamics of gas bubbles in peat deposits significantly affects hydrological conditions and hydraulic properties (Kellner et al., 2004, 2005). For instance, hydraulic conductivity reduces in value with an increase in volume of entrapped gas bubbles (Beckwith and Baird, 2001; Kellner et al., 2005). Other aspects of biological activity, including clogging of the pores by bacterial mass or nongaseous products of bacterial respiration, are also responsible for reductions in hydraulic conductivity (Beckwith and Baird, 2001). Since rates of primary consolidation and creep settlements are governed by drainage and sequential expulsion of water from macro- and micropores (Berry, 1983; Huat et al., 2011), reductions in hydraulic conductivity significantly reduce the settlement rate, exacerbating the long-term settlement problem. Although an abundance of 
gas bubbles (mainly methane) can be found at depth in peat deposits under anaerobic condition (Kellner et al., 2004), potential effects arising from reductions in hydraulic conductivity due to entrapped gases are currently largely ignored in considering peat compressibility.

Probable positive impacts of the decomposition process are reductions in future compression potential of the degraded peat on account of structural changes and rearrangement of constituent fibres that have already taken place and changes in the manner in which water is held and expelled between micropores and macropores (Hobbs, 1986; Mesri and Ajlouni 2007). Destruction of the physical structure of the organic matter with increasing degree of decomposition produces smaller equi-dimensional organic grains that pack together more tightly, manifesting in a firmer structure and producing higher values of bulk/dry density and lower void ratio (Landva and Pheeney, 1980; Price et al., 2005; Mesri and Ajlouni, 2007; Huat et al., 2011). The effective diameter of the pores reduces considerably, resulting in lower permeability, and changes in shape of the flow channels reduce the degree of permeability anisotropy (Huang et al., 2009; O'Kelly, 2006; Mesri and Ajlouni, 2007). Scale and fibre effects can have significant bearing on measured mechanical and hydraulic properties of fibrous peat (Long, 2005; Zwanenburg, 2005; O'Kelly and Zhang, 2013). Ideally the test-specimen should be large enough to adequately reflect the mini structure of the in-situ peat deposit. For instance, O'Kelly (2007) reported that hydraulic conductivity values determined from constant head permeability tests performed on undisturbed slightly decomposed fibrous peat specimens, $76.2-\mathrm{mm}$ in diameter by $19.0 \mathrm{~mm}$ high, were typically between one or two orders of magnitude lower than had been expected in-situ, which was explained by scale effects. O'Kelly and Zhang (2013) have also shown that the reproducibility of triaxial consolidation tests performed on 38-mm diameter fibrous peat specimens is generally poor. In this regard, O'Kelly (2008, 2009) developed a floating-ring consolidometer that accommodates $152-\mathrm{mm}$ diameter by up to $300 \mathrm{~mm}$ long testspecimens and allowes direct measurement of the hydraulic conductivity over low to medium stress levels and constant-head low Reynolds Number (laminar) flow, typical of in-situ conditions, and for which Darcy's Law has been shown to be valid (Hemond and Goldman, 1985). Edil and den Haan (1994) and O'Kelly and Zhang (2013) also reported that estimations of the time period required to achieve substantial completion of the primary consolidation phase (which are later used in calculating hydraulic conductivity values) should preferably be deduced from pore-water pressure measurements, rather than the settlement or volume change response, which is generally too conservative an approach.

The general consensus in geotechnical literature that the compressibility of peat reduces with increasing degree of decomposition (Hobbs, 1986; Price et al., 2005) is demonstrated in Figures 7 and 8. Figure 7 indicates that the compressibility (characterized by measured coefficient of volume change, $\mathrm{m}_{\mathrm{v}}$, values) of Canadian peats reduced with increasing von Post number, most strikingly for fibric peat (i.e. H1 to H4). Test-specimens of the same peat type were sampled from different depths over a vertical profile and hence were naturally at different stages of decomposition. Comparing the void ratio against effective stress relationships for Canadian amorphous peat and Irish fibrous peat in Figure 8, the reduction in void ratio for a given effective stress level (i.e. creep) are significantly lower for amorphous peat compared with fibrous peat. The impact of decomposition can also be demonstrated using the void ratio against compression index data for fen, transitional and bog peats shown in Figure 9. Fen peat is alkaline and more likely to be highly decomposed (Hobbs, 1986); confirmed by generally lower values of initial 
void ratio and compression index compared with the least decomposed acidic peats. This finding is supported by Duraisamay et al. (2007) from measurements of compression index for fibric, hemic and sapric peats from tropical regions (Figure 10), with the trend of decreasing compressibility from fibrous to amorphous peats evident. These data also clearly demonstrate specimen scale and fibre effects on measured material properties, especially for fibric peat, with $150-\mathrm{mm}$ diameter by $50 \mathrm{~mm}$ high specimens tested in the Rowe cell and $50-\mathrm{mm}$ diameter by 20 $\mathrm{mm}$ high specimens tested in the oedometer apparatus.

Figure 7. Compressibility of Canadian peats at different states of decomposition (adapted from Price et al. (2005)).

Figure 8. Void ratio-effective stress-time relationships for fibrous and amorphous peats (adapted from Hobbs (1986)).

Figure 9. Void ratio against compression index for peats of different origin (adapted from Hobbs (1986)).

Figure 10. Compressibility index against consolidation pressure for tropical peats (adapted from Duraisamay et al. (2007)).

The decomposition process may also reduce long-term compression, considering creep settlement is associated with the high compressibility of the organic solids and porosity of the peat fibres (Berry, 1983; Landva and La Rochelle, 1983). The breakdown of the cells and baffle walls that reinforce the peat fibres reduces the level of future deformation of the degraded fibres under loading since destructed fibres are less susceptible to plastic deformation (Landva and La Rochelle, 1983; Farrell, 2012). However there is a dearth of experimental data in literature. Consider first the prediction of the compressibility of geomaterials using the law of compressibility based on the $C_{\alpha} / C_{\mathrm{c}}$ ratio (Mesri and Ajlouni, 1997); where $C_{\mathrm{c}}$ and $C_{\alpha} \Leftarrow \Delta e / \Delta \log t_{\text {- }}$ are indices of primary and secondary compression respectively. Materials having higher values of $C_{\alpha} / C_{\mathrm{c}}$ usually undergo larger creep settlement. For peat, the magnitude of $C_{\alpha} / C_{\mathrm{c}}$ depends on the compressibility and deformability of the solids, with values typically in the range of 0.04 to 0.06, up to a maximum of about 0.1 (Hobbs, 1986; Huang et al., 2009). Values for fibrous and amorphous peats are usually towards the higher and lower ends of this range, respectively (Hobbs, 1986; Mesri and Ajlouni, 1997), from which it may be inferred that under higher states of decomposition, peat undergoes reduced creep settlement. In the study by Colleselli et al. (2000), single load stage oedometer tests (with the applied stress increased from 10 to $100 \mathrm{kPa}$ ) were performed on three Italian peats, all having the same reported organic content of $71-72 \%$ by dry mass. Note peats having approximately the same organic content but 
existing at different states of decomposition will have different fibre contents (as was the case in this study) since the standard method for fibre content determination (ASTM D1997, 2008) only considers fibres retained on the $150-\mu \mathrm{m}$ sieve. Referring to Figure 11 and focusing specifically on the long-term response (i.e. loading period $>10^{4} \mathrm{~min}$ ), as a proportion of the total settlement, the Adria-1 and Correzzola peats, experienced relatively small secondary and tertiary compression compared with Adria-2 peat. This may be explained by considering the measured fibre contents of $75 \%$ for Adria-2 peat (von Post H3-4) and $25 \%$ for both Adria-1 and Correzzola peats (H6 and H5 respectively). Adria-2 peat has a low primary compression, usually merging with the secondary compression. Colleselli et al. (2000) stated that Adria-1 and Correzzola peats showed a curve having clear primary consolidation and secondary compression components. The Adria-2 peat has the highest fibre content and shows the greatest tertiary settlement. Since organic content was similar, they attributed the different long-term behaviour of the three peats to the difference in fibre content. Hence, as fibre content reduces for higher states of decomposition, it is argued that reduced secondary and tertiary compression occur in peats having higher states of decomposition. However further laboratory and especially field studies are required in order to confirm these observations.

Figure 11. Settlement against time response for three Italian peats (adapted from Colleselli et al. (2000)).

\section{CONCLUSIONS}

Plant fibres in peat have the potential to decompose further, either naturally or as a result of anthropogenic activity. The population of microorganisms in fibrous Sphagnum peat is typically of the order of $10^{5}$ colony-forming units per gram solids, although this increases by many folds under more favourable conditions of oxygen supply, $\mathrm{pH}$, temperature and $\mathrm{C}: \mathrm{N}$ ratio. Decomposition is accompanied by a progressive destruction of the peat fabric, reductions in size and strength of the fibres and change in chemical state (loss in volume of solids, transformation of organic matter into more recalcitrant humic substances and biogas generation), which significantly affect the physical and mechanical properties, hydrological condition and hydraulic properties of the peat deposit. More decomposed peat generally undergoes lower primary consolidation and creep settlements, and is also less prone to further decomposition, compared with lesser decomposed peat.

Uncontrolled or unexpected decomposition occurring in fibrous peat deposits may cause significant additional settlement of bearing strata, adversely impacting on the performance of engineering structures founded on or within such deposits. Taking a different approach, it is plausible that by increasing biological activity in order to accelerate the decomposition process in fibrous peat, thereby producing a more recalcitrant bearing material in advance of the main construction works, may provide the basis for a ground improvement strategy. A similar type philosophy has been advanced for municipal landfill construction, in which post-filling settlement can be significantly reduced by creating conditions favourable to accelerating the decomposition process during the active filling stage. In the case of fibrous peat, experimental laboratory trials have shown that microorganism populations, and hence the decomposition rate, 
can be accelerated markedly by adding sufficient amounts of basic and nitrogenous materials to the peat in order to adjust its $\mathrm{C}: \mathrm{N}$ ratio and $\mathrm{pH}$ values within the range of $15: 1$ to $30: 1$ and $7.0-$ 7.5 respectively.

\section{ACKNOWLEDGEMENT}

The second writer gratefully acknowledges a research scholarship award from the Public Service Department of Malaysia. The writers thank the reviewers for their helpful comments.

\section{REFERENCES}

ASTM 2007. Standard Classification of Peat Samples by Laboratory Testing, D4427-07. ASTM International, West Conshohocken, PA, USA.

ASTM 2008. Standard Test Method for Laboratory Determination of the Fiber Content of Peat Samples by Dry Mass, D1997-91. ASTM International, West Conshohocken, PA, USA.

Barns, S.M., and Nierzwicki-Bauer, S.A. 1997. Microbial diversity in modern subsurface, ocean, and surface environments. In Geomicrobiology: Interactions Between Microbes and Minerals (Banfield JF and Nealson KH (eds)). Reviews in Mineralogy Vol. 35. Ch. 2, pp. 35-71. Mineralogical Society of America, Washington, DC, USA.

Berry, P.L. 1983. Application of consolidation theory for peat to design of a reclamation scheme by preloading. Quarterly Journal of Engineering Geology, 16(9): 103-112.

Beckwith, C.W., and Baird, A.J. 2001. Effects of biogenic gas bubbles on water flow through poorly decomposed blanket peat. Water Resources Research, 37(3): 551-558.

Couwenberg, J. 2009. Methane emissions from peat soils (organic soils, histosols). Wetlands International, Ede, The Netherlands, pp. 14.

Collesilli, F., Cortellazzo, G., and Cola, S. 2000. Laboratory testing of Italian peat soils. Geotechnics of High Water Content Materials, ASTM STP 1374, T.B. Edil and P.J. Fox, Eds., American Society of Testing and Materials, pp. 226-240.

Cuddy, T. 1988. The Behaviour of Bog Road Pavements. Masters (MAI) Thesis, University of Dublin, Trinity College, Dublin.

Dhowian, A.W., and Edil, T.B. 1980. Consolidation behavior of peats. ASTM Geotechnical Testing Journal, 3(?): 105-114.

Drajad, M, Soekodarmodjo, S., Hidayat, M.S., and Nitisapto, M. 2003. Subsidence of peat soils in the tidal swamplands of Barambai, South Kalimantan. Jurnal Ilmu Tanah dan Lingkungan, 4(1): 32-40.

Duraisamy, Y., Huat, B.B.K., and Aziz, A.A. 2007. Engineering properties and compressibility behaviour of tropical peat soil. American Journal of Applied Sciences, 4(10): 765-770.

Edil, T.B., and den Haan, E.J. 1994. Settlement of peats and organic soils. ASCE Geotechnical Special Publication, 40(2): 1543-1572.

Farrell, E.R. 2012. Chapter 32: Organics/peat soils. Manual of Geotechnical Engineering. Proceedings of the Institution of Civil Engineers. pp. 463-479.

Hemond, H.F., and Goldman, J.C. 1985. On non-Darcian water flow in peat. Ecology, 73: 579584. 
Hobbs, N.B. 1986. Mire morphology and the properties and behaviour of some British and foreign peats. Quarterly Journal of Engineering Geology, 19(1): 7-80.

Huang, P., Patel, M., Santagata, M.C., and Bobet, A. 2009. Classification of Organic Soils. Publication FHWA/IN/JTRP-2008/02. Joint Transportation Research Program, Indiana Department of Transportation and Purdue University, West Lafayette, Indiana, 2009. doi: $10.5703 / 1288284314328$

Huat, B.K., Asadi, A., and Kazemian, S. 2009. Experimental investigation on geomechanical properties of tropical organic soils and peat. American Journal of Engineering and Applied Sciences, 2(1): 184-188.

Hunter, P.J., Petch, G.M., Calvo-Bado, L.A., Pettitt, T.R., Parsons, N.R., Morgan, J.A., and Whipps, J.M. 2006. Differences in microbial activity and microbial populations of peat associated with suppression of damping-off disease caused by Phythium sylvaticum. Applied and Environmental Microbiology, 72(10): 6452-6460.

Huat, B.K., Kazemian, S., Prasad, A., and Barghchi, M. 2011. State of an art review of peat: General perspective. International Journal of the Physical Sciences, 6(8): 1988-1996.

Kazemian, S., Huat, B.B.K., Prasad, A., and Barghchi, M. 2011. A state of art review of peat: Geotechnical engineering perspective. International Journal of the Physical Sciences, 6(8): 1974-1981.

Kellner, E., Waddington, J.M., and Price, J.S. 2004. Pressure variation in peat as a result of gas bubble dynamics. Hydrological Processes, 18(13): 2599-2605.

Kellner, E., Waddington, J.M., and Price, J.S. 2005. Dynamics of biogenic gas bubbles in peat: potential effects on water storage and peat deformation. Water Resources Research, 41(8), W08417, doi:10.1029/2004WR003732.

Landva, A.O., and Pheeney, P.E. 1980. Peat fabric and structure. Canadian Geotechnical Journal, 17(3): 416-435.

Landva, A.O., and La Rochelle, P. 1983. Compressibility and shear characteristics of Radforth peats. Testing of Peats and Organic Soils, ASTM STP 820, P.M. Jarrett, Ed., American Society of Testing and Materials, pp. 157-191.

Lévesque, M.P. and Mathur, S.P. 1979. A comparison of various means of measuring the degree of decomposition of virgin peat materials in the context of their relative biodegradability. Canadian Journal of Soil Science, 59(4): 397-400.

Long, M. 2005. Review of peat strength, peat characterization and constitutive modeling of peat with reference to landslides. Studia Geotechnica et Mechanica, 27(3/4): 67-90.

Matthiesen, H. 2004. State of Preservation and Possible Settling of Cultural Layers Below Bredsgarden and Bugaden Tenements, Bryggen, Bergen. Department of Conservation, National Museum of Denmark, Report No. 10832-0004-3.

Mesri, G., and Ajlouni, M. 1997. Secondary compression of peat with or without surcharging. ASCE Journal of Geotechnical and Geoenvironmental Engineering, 123(5): 411-421.

Mesri, G., and Ajlouni, M. 2007. Engineering properties of fibrous peat. ASCE Journal of Geotechnical and Geoenvironmental Engineering, 133(7): 850-866.

Mitchell, J.K., and Santamarina, J.C. 2005. Biological considerations in geotechnical engineering. ASCE Journal of Geotechnical and Geoenvironmental Engineering, 131(10): 1222-1233.

Ng, S.Y., and Eischens, G.R. 1983. Repeated short-term consolidation of peats. Testing of Peats and Organic Soils, ASTM STP 820, P.M. Jarrett, Ed., American Society of Testing and Materials, pp. 192-206. 
O'Kelly, B.C. 2005. Consolidation properties of a dewatered municipal sewage sludge. Canadian Geotechnical Journal, 42(5): 1350-1358. doi: 10.1139/T05-054

O’Kelly, B.C. 2006. Compression and consolidation anisotropy of some soft soils. Geotechnical and Geological Engineering, 24(6): 1715-1728. doi: 10.1007/s10706-005-5760-0

O'Kelly, B.C. 2007. Compressibility and permeability anisotropy of some peaty soils. Proceedings of the $60^{\text {th }}$ Canadian Geotechnical Conference, Vol. 3, pp. 1934-1939. Ottawa, Ontario, 21 ${ }^{\text {st }}$-23rd October 2007. Canadian Geotechnical Society.

O'Kelly, B.C. 2008. Development of a large consolidometer-permeameter apparatus for testing soft soils. Proceedings ASCE GeoCongress 2008: Challenge of Sustainability in the Geoenvironment, New Orleans, Louisiana, USA, 9 ${ }^{\text {th }}-12$ th March 2008. Eds. A.N. Alshawabkeh, K.R. Reddy and M.V. Khire. Vol. 5, pp. 60-67. doi: 10.1061/40972(311)8. American Society of Civil Engineers.

O'Kelly, B.C. 2009. Development of a large consolidometer apparatus for testing peat and other highly organic soils. Suo-Mires and Peat, 60(1/2): 23-26.

O'Kelly, B.C. 2013. Characterisation and undrained strength of amorphous clay. Proceedings of the Institution of Civil Engineers, Geotechnical Engineering. Currently only available in Ahead of Print version. URL: www.icevirtuallibrary.com/content/article/10.1680/geng.11.00025 doi: 10.1680/geng.11.00025

O'Kelly, B.C., and Zhang, L. 2013. Consolidated-drained triaxial compression testing of peat, ASTM Geotechnical Testing Journal, 36(3). 12pp. doi: 10.1520/GTJ20120053

Osorio J.P., Farrell E.R., O'Kelly B.C. and Casey T., 2008. Rampart roads in the peat lands of Ireland: genesis, development and current performance. Proceedings of the First International Conference on Transportation Geotechnics, Nottingham, UK, 25 ${ }^{\text {th }}-27$ th August 2008. Eds. E. Ellis, H-S. Yu, G. McDowell, A.R. Dawson, N. Thom. Vol. 1, pp. 227-233. Leiden, Netherlands : CRC Press/Balkema.

Oweis, I.S. 2006. Estimate of landfill settlements due to mechanical and decompositional processes. ASCE Journal of Geotechnical and Geoenvironmental Engineering, 132(5): 644-650.

Pankratov, T.A., Ivanova, A.O., Dedysh, S.N., and Liesack, W. 2011. Bacterial populations and environmental factors controlling cellulose degradation in an acidic Sphagnum peat. Environmental Microbiology, 13(7), 1800-1814.

Pichan, S.P., and O'Kelly, B.C. 2012. Effect of decomposition on the compressibility of fibrous peat, ASCE GeoCongress 2012: State of the Art and Practice in Geotechnical Engineering, Oakland, California, USA, 25th-29th March, 2012, edited by R.D. Hryciw, A. Athanasopoulos-Zekkos and N. Yesiller, (GSP 225), pp. 4329 - 4338. Reston, Va.: American Society of Civil Engineers. doi: 10.1061/9780784412121.445

Pichan, S.P., and O'Kelly, B.C. 2013. Stimulated decomposition in peat for engineering applications. Proceedings of the Institution of Civil Engineers, Ground Improvement. Vol. 166. 9 pp. Currently only available in Ahead of Print version.

URL: http://www.icevirtuallibrary.com/content/article/10.1680/grim.12.00003 doi: 10.1680/grim.12.00003

Price, J.S., Cagampan, J., and Kellner, E. 2005. Assessment of peat compressibility: is there an easy way? Hydrological Processes, 19(17): 3469-3475.

Santagata, M., Bobet, A., Johnston, C.T., and Hwang, J. 2008. One dimensional compression behaviour of a soil with a high organic matter content. ASCE Journal of Geotechnical and Geoenvironmental Engineering, 134(1): 1-13. 
Schnitzer, M. 1967. Humic-fulvic acid relationships in organic soils and humification of the organic matter in these soils. Canadian Journal of Soil Science, 47(3): 245-250.

Rochus, W. and Sipos, S. 1976. Degree of humification and composition of the humus complex from different low bogs. Proceedings of the 5th International Peat Congress, Poznań, Poland, 21-25th September 1976. Vol. 2, pp. 320-328. Warsaw: Wydawnictwa Czasopism Technicznych NOT.

Tate, R.L. 1987. Soil Organic Matter: Biological and Ecological Effects. John Wiley \& Sons, New York.

Wardwell, R.E., Charlie, W.A., and Doxtader, K.A. 1983. Test method for determining the potential for decomposition in organic soils. Testing of Peats and Organic Soils, ASTM STP 820, P.M., Jarrett, Ed., American Society of Testing and Materials, pp. 218-229.

Wong, L.S., Hashim, R., and Ali, F. 2008. Engineering behaviour of stabilized peat soils. European Journal of Scientific Research, 21(4): 581-591.

Wong, L.S, Hashim, R., and Ali, F.H. 2009. A review on hydraulic conductivity and compressibility of peat. Journal of Applied Sciences, 9(18): 3207-3218.

Yamaguchi, H., Ohira, Y., Kogure, K., and Mori, S. 1985. Undrained shear characteristics of normally consolidated peat under triaxial compression and extension conditions. Japanese Society of Soil Mechanics and Foundation Engineering, 25(3): 1-18.

Zhang, L., and O'Kelly, B.C. 2013. The principle of effective stress and triaxial compression testing of peat. Proceedings of the Institution of Civil Engineers, Geotechnical Engineering, $11 \mathrm{pp}$. Currently only available in Ahead of Print version.

URL: http://www.icevirtuallibrary.com/content/article/10.1680/geng.12.00038 doi: 10.1680/geng.12.00038

Zwanenburg, C. 2005. The influence of anisotropy on the consolidation behaviour of peat. $\mathrm{PhD}$ Thesis, Delft University of Technology, Delft University Press. 


\section{Figures 1 to 11:}

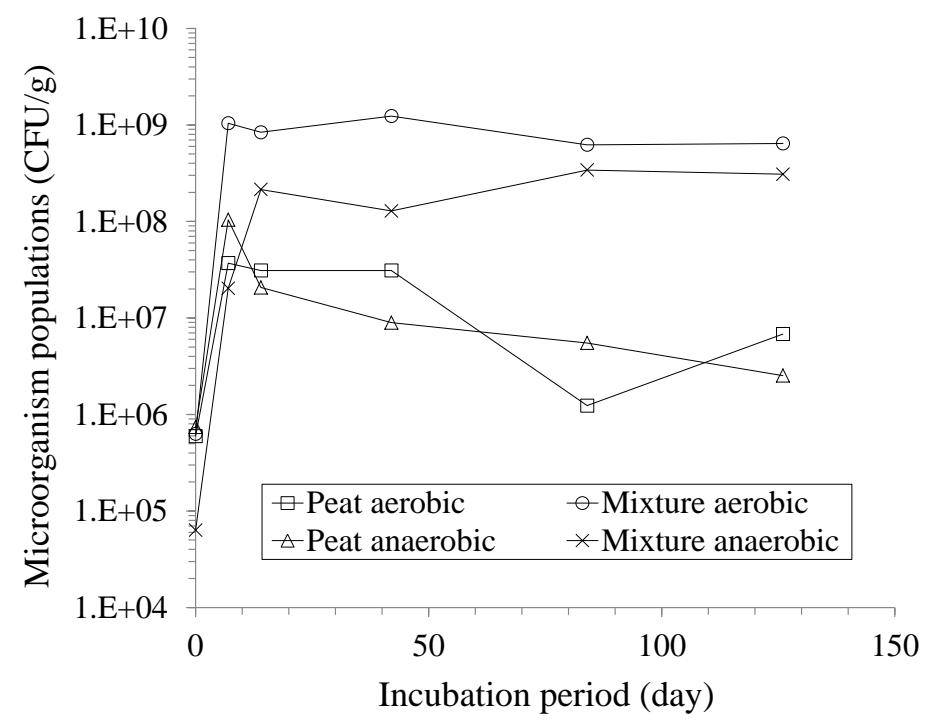

Figure 1: Population of microorganisms in natural peat and peat-PPFA-urea mixture at $30^{\circ} \mathrm{C}$ against duration of incubation period.

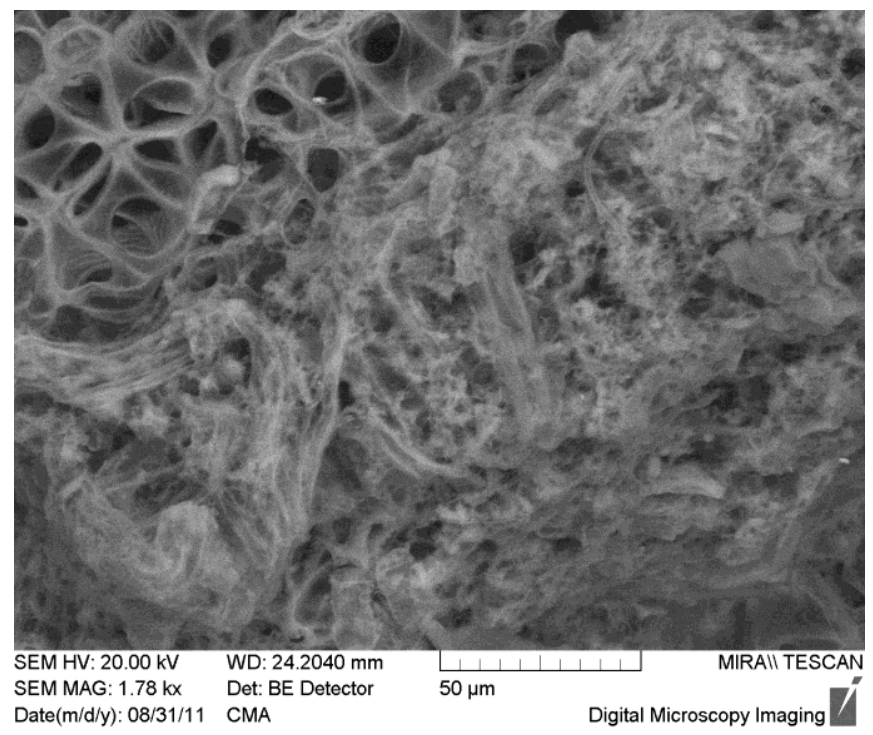

Figure 2. Scanning electron micrograph of pseudo-fibrous Sphagnum peat. 


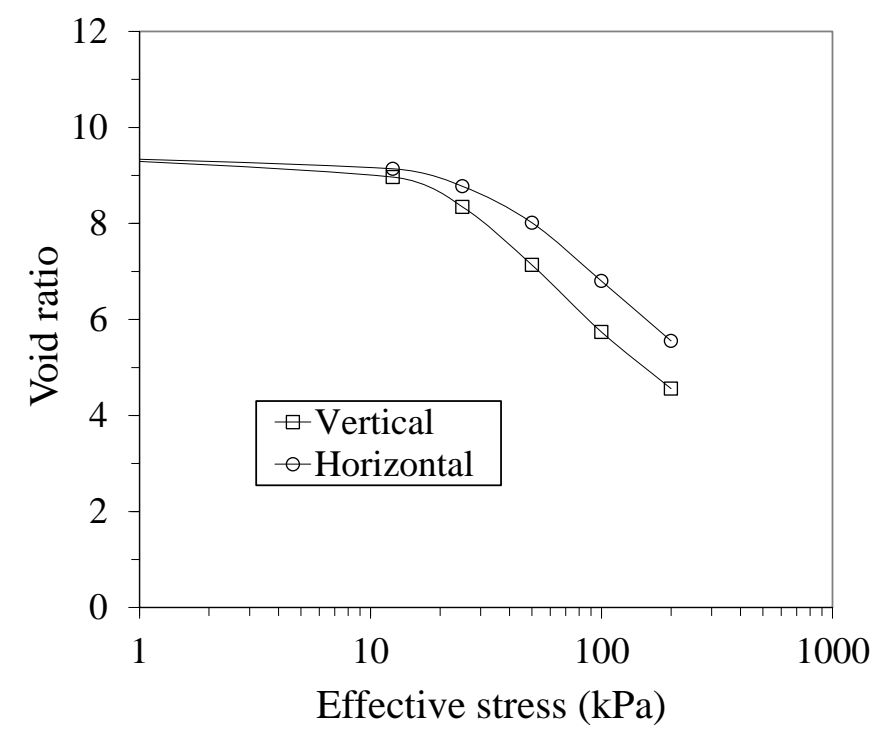

Figure 3. Compression properties of fibrous peat for vertical and horizontal loading directions (adapted from O'Kelly (2006)).

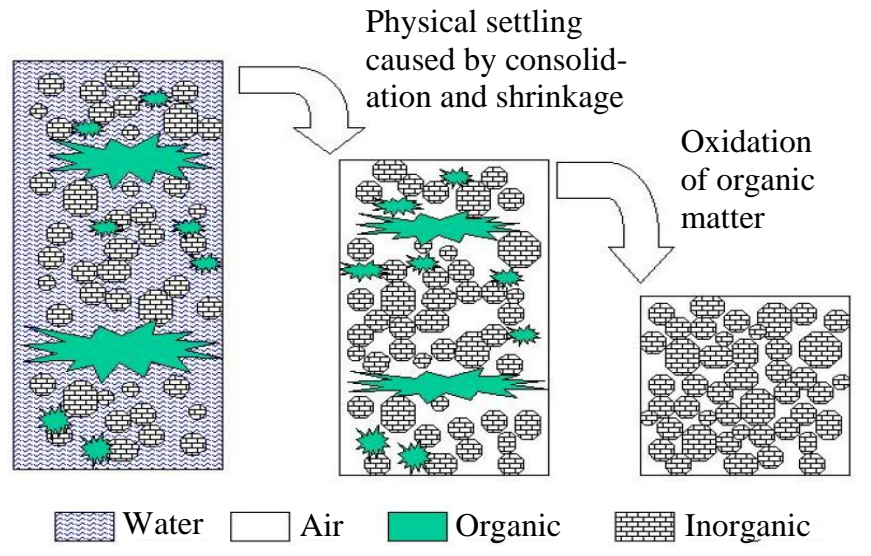

Figure 4. Settlement response caused by lowering of the groundwater table (adapted from Matthiesen (2004)). 


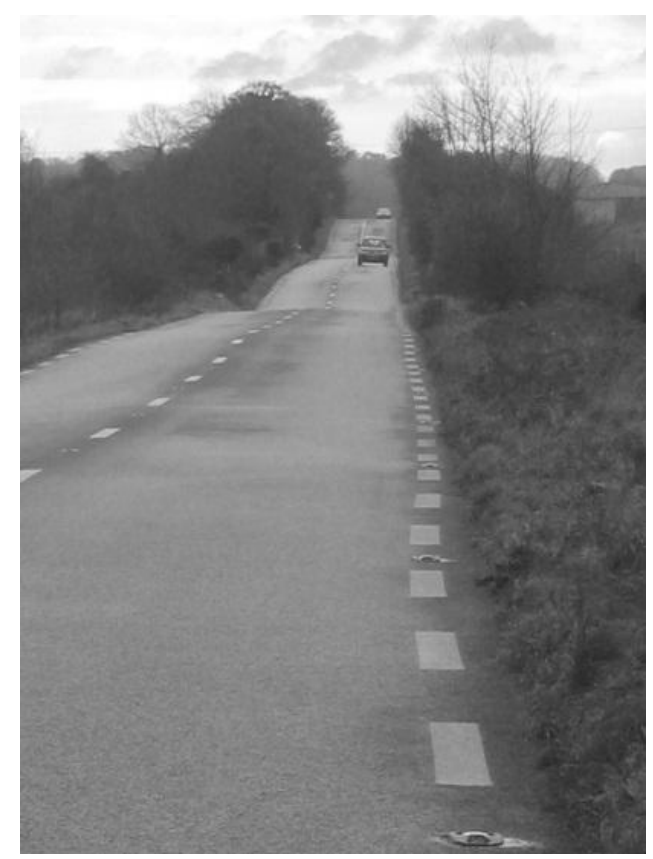

Figure 5. Extreme undulations on N62 rampart road, Ireland (Osario et al. 2008). 


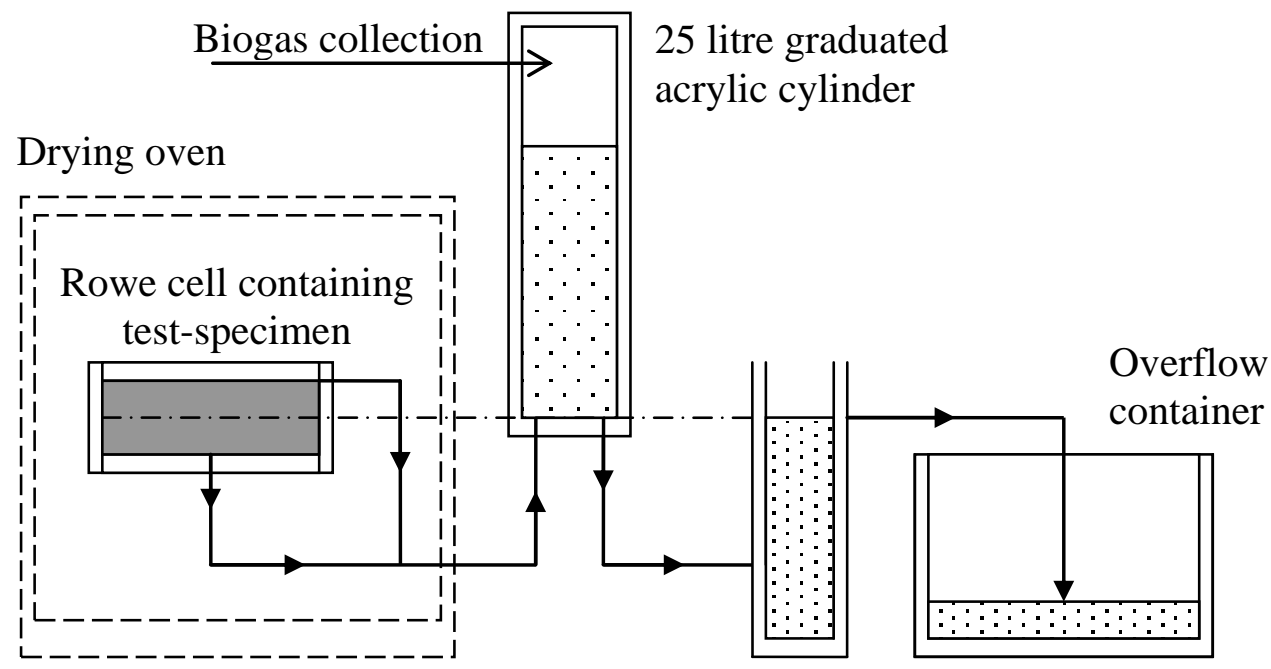

(a) Anaerobic biodegradation at elevated temperature (adapted from O’Kelly (2005)).

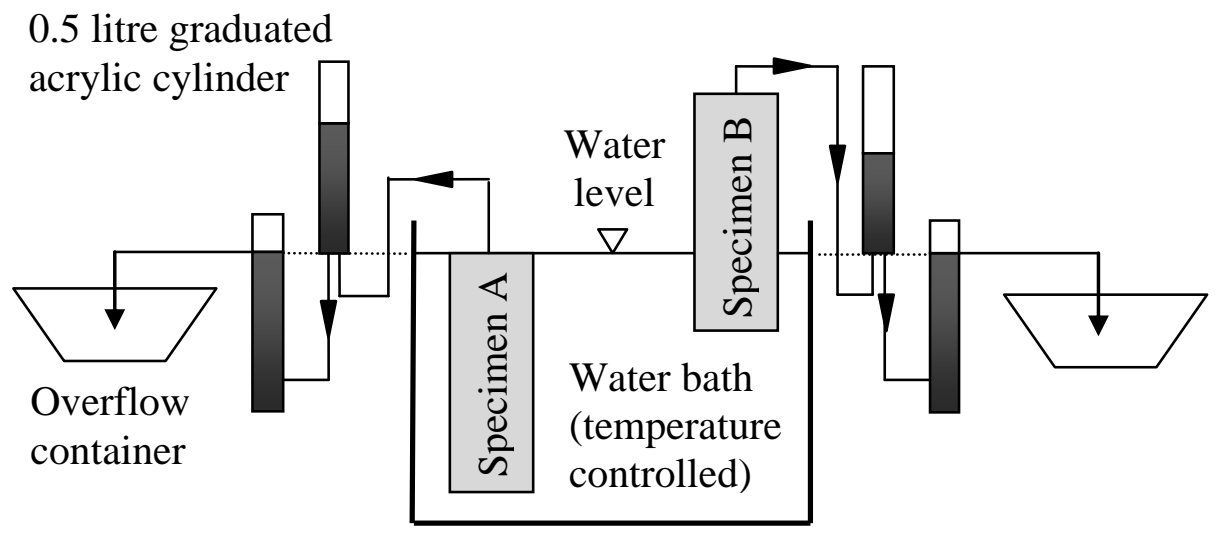

(b) Incubation of submerged and partially submerged peat cores (adapted from Pichan and O'Kelly (2012)).

Figure 6. Set-ups to measure volume of biogas evolving from peat and other highly organic soils. 


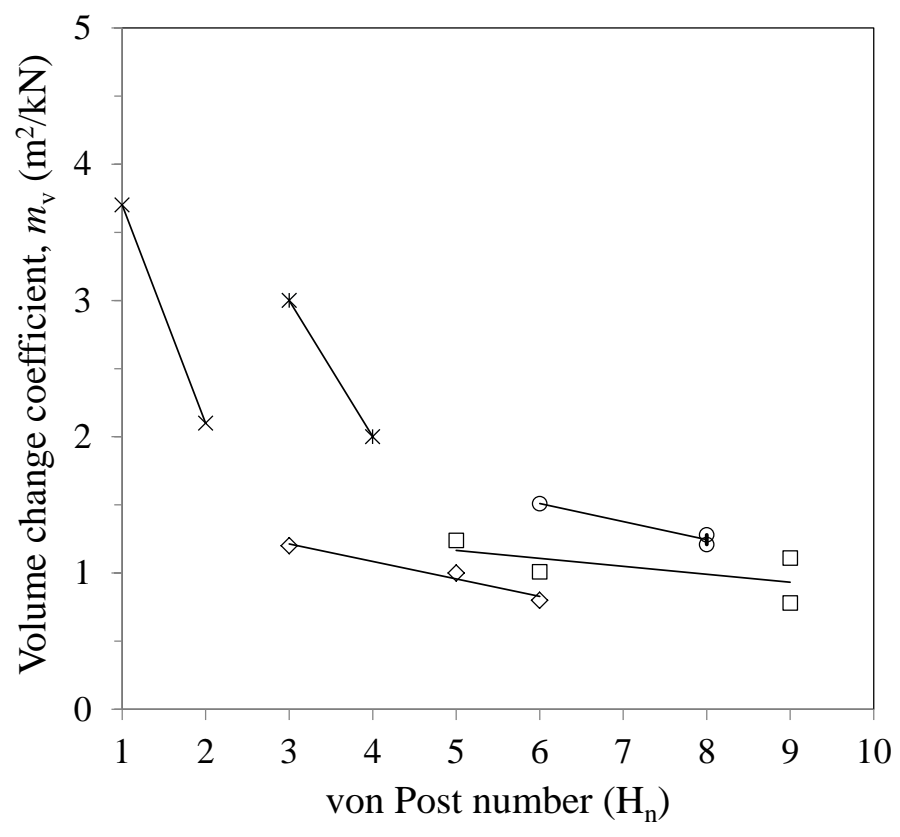

Figure 7. Compressibility of Canadian peats at different degrees of decomposition (adapted from Price et al. (2005)).

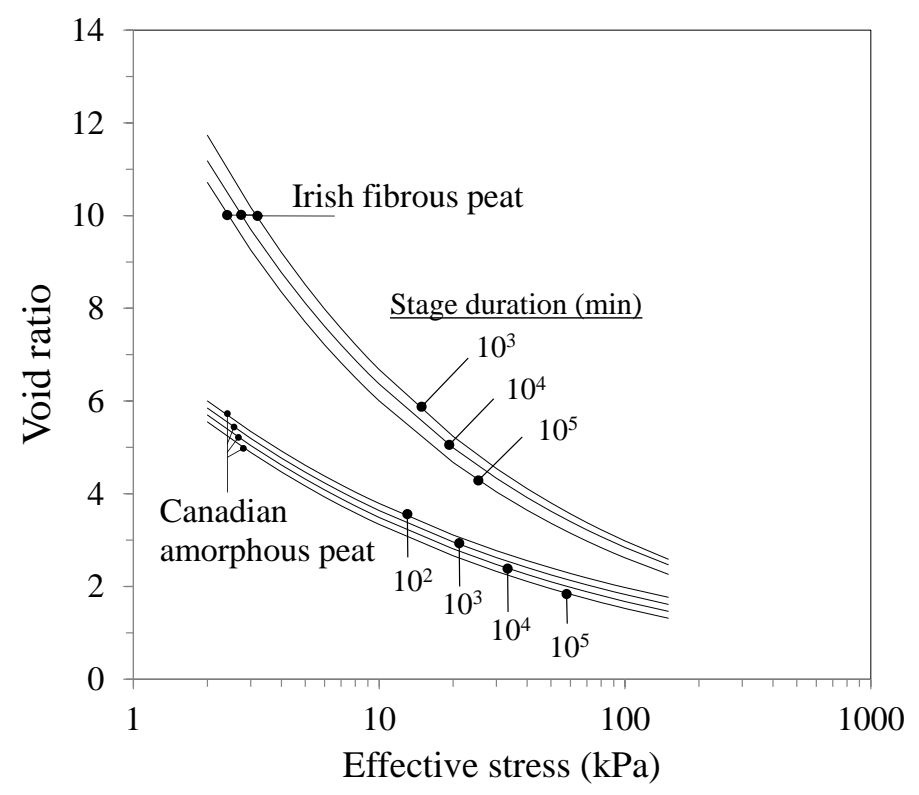

Figure 8. Void ratio-effective stress-time relationships for fibrous and amorphous peats (adapted from Hobbs (1986)). 


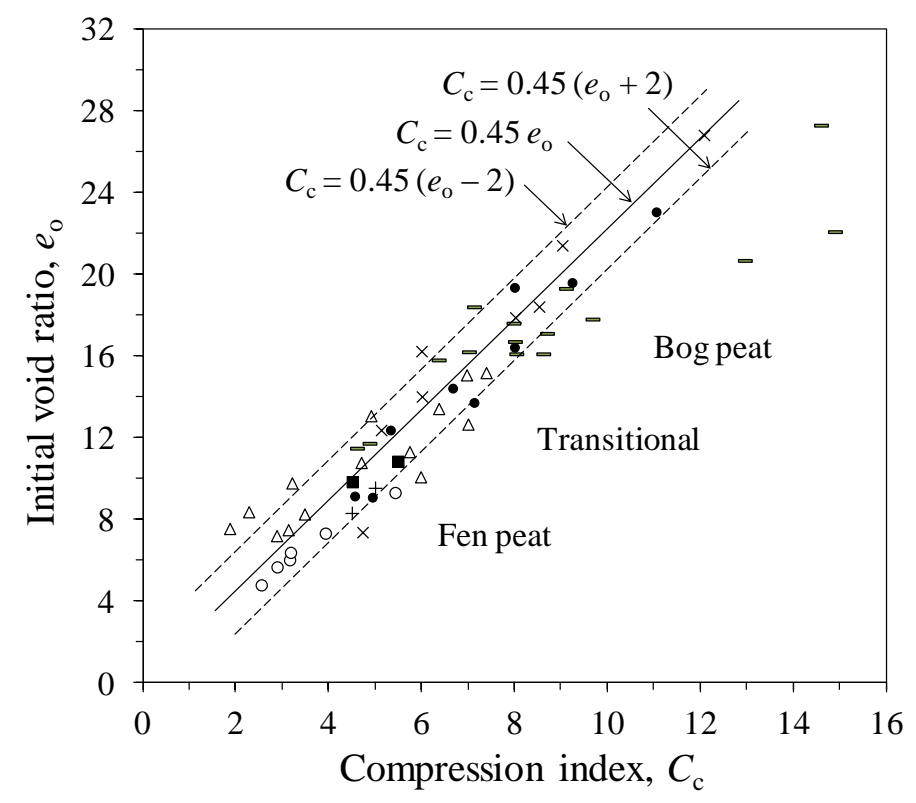

Figure 9. Void ratio against compression index for peats of different origin (adapted from Hobbs (1986)).

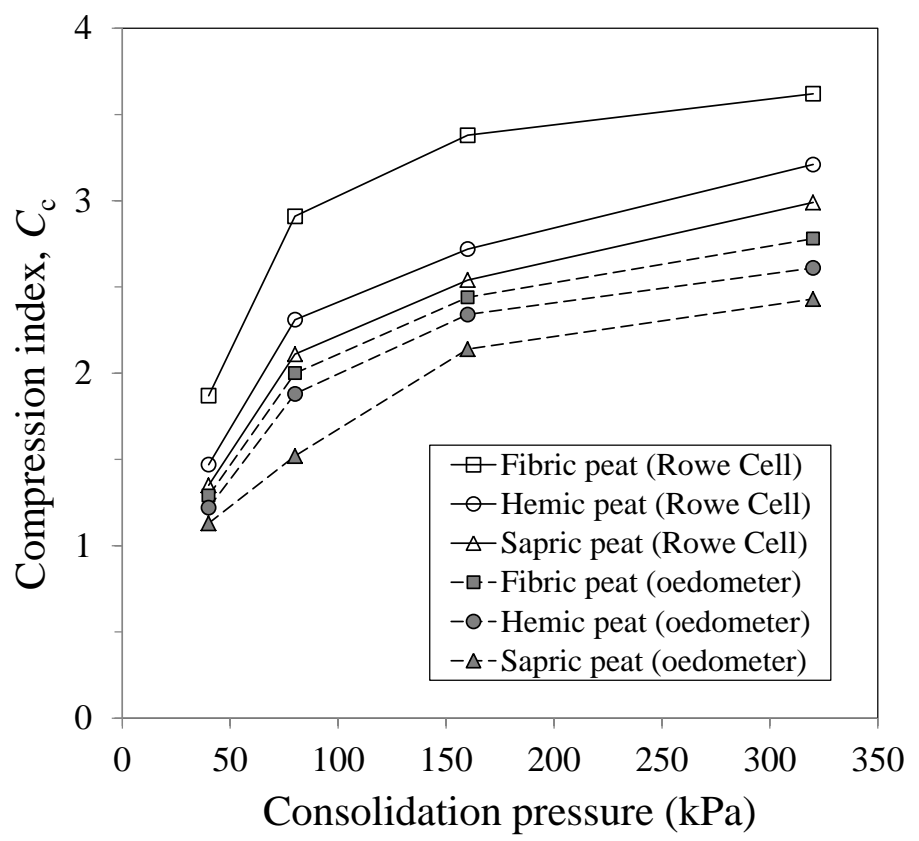

Figure 10. Compressibility index against consolidation pressure for tropical peats (adapted from Youventharan et al. (2007)). 


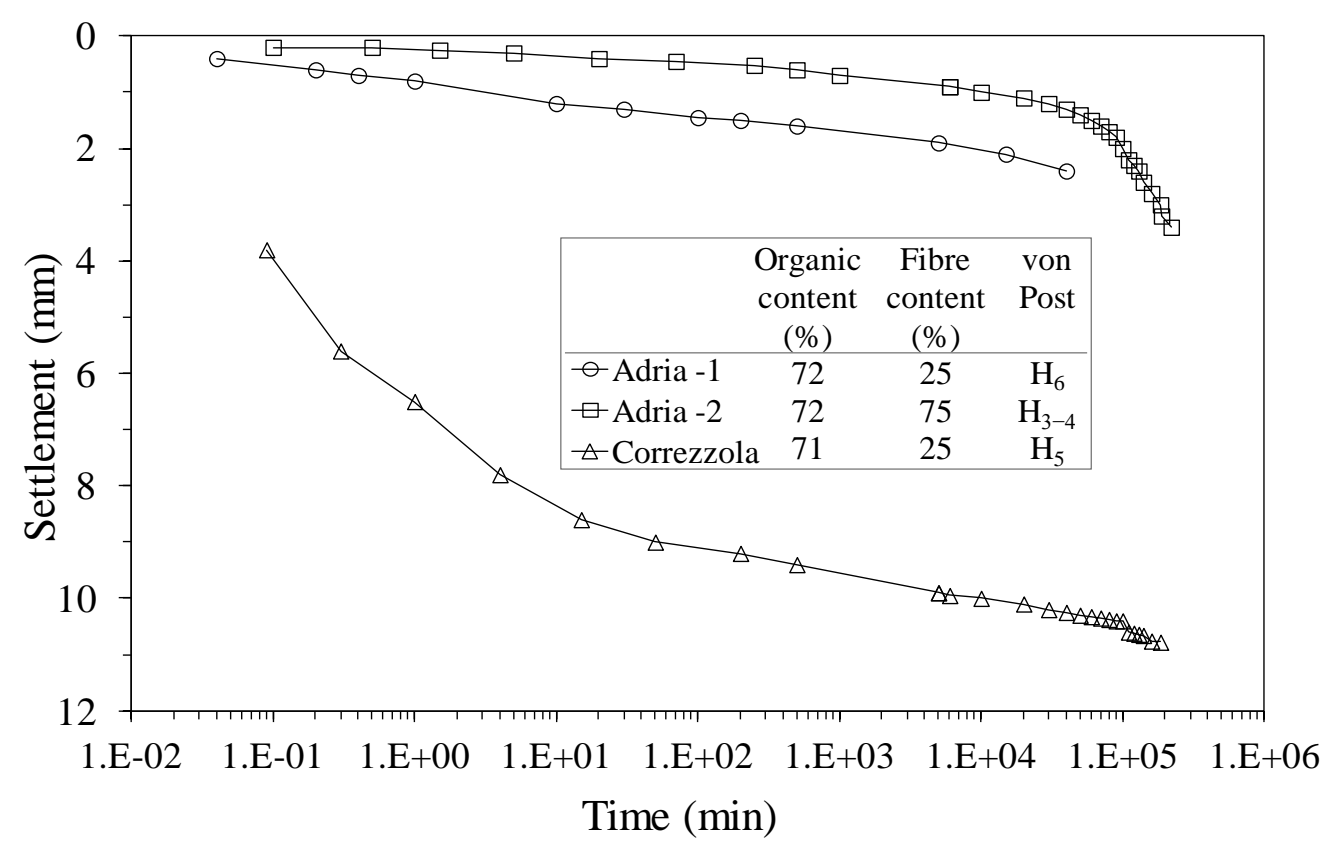

Figure 11. Settlement against time response for three Italian peats (adapted from Colleselli et al. (2000)). 